\title{
THE ROLE OF MUNICIPALITIES IN RELATION TO NON-GOVERNMENTAL ORGANIZATIONS: IMPLEMENTATION OF PUBLIC POLICIES TOWARDS NGOS AT THE LOCAL LEVEL
}

ROLE OBCÍ VE VZTAHU K NESTÁTNÍM NEZISKOVÝM
ORGANIZACÍM: IMPLEMENTACE VEŘEJNÉ POLITIKY VƯČI
NESTÁTNÍM NEZISKOVÝM ORGANIZACÍM NA OBECNÍ ÚROVNI.

\section{Ing. ZuZana PROUZOVÁ, Ph.D.}

\author{
Katedra veřejné ekonomie $\mid$ Department of Public Economics \\ Ekonomicko-správni fakulta Faculty of Economics and Administration \\ Masarykova univerzita Masaryk University \\ $\triangle$ Lipová 4la, 60200 Brno, Czech Republic \\ E-mail: Zuzana.Prouzova@econ.muni.cz
}

\begin{abstract}
Annotation
The Czech Republic's subsidy policy towards non-governmental organizations (NGOs) is centrally coordinated by the government to support selected legal forms: foundations, endowment funds, public benefit corporations, church organisation and civic associations. The relationship between the state and NGOs in the Czech Republic takes the form of a conceptual framework set to create an appropriate environment for the existence and work of NGOs and for the forms of financial and inkind support to NGOs. Cooperation between NGOs and public administrations and support provided to NGOs from public budgets takes place at the regional level as well. At the regional level, as at the national level, the relationship is usually conceptually grounded. However, what is the situation like at the municipal level? Is it necessary to formalize the relationship between public administration and $N G O s$ at the municipal level? Do the motives for support provided to NGOs at the municipal level differ from those at higher levels of public administration? What forms does the support of NGOs take at the local level? These questions are answered in the paper through a representative survey, which was conducted in 2012 with respondents from the municipal offices in the Czech Republic, and through an analysis of secondary data sources. The research results show a high degree of cooperation between municipalities and NGOs, a high level of indirect support to NGOs at the municipal level, and concurrently a low level of formalization and a legal documentation confirming such relationships. Support to NGOs is implemented informally.
\end{abstract}

Key words

municipalities, NGOs, public policy, funding, indirect support

\section{Anotace}

Státní dotačni politika České republiky vůči nestátním neziskovým organizacím je vládou centrálně koordinovanou politiku zaměrenou na podporu vybraným právnich forem právnických osob, kterými jsou nadace, nadačni fondy, obecně prospěšné společnosti, účelová zařizeni cirkví a občanská sdružení. Tento vztah státu a nestátních neziskových organizaci $v \stackrel{C}{R}$ nabývá formy koncepčního nastaveni vhodného prostředi pro existenci a činnost nestátnich neziskových organizaci v České republice ale také $i$ formy finančni $i$ nefinančni podpory nestátnich neziskových organizací. Spolupráce nestátnich neziskových organizaci a veřejné správy a podpora nestátnich neziskových organizaci z veřejných rozpočtů probihá $i$ na regionálni úrovni. Na krajské úrovni podobně jako na státni úrovni bývá koncepčně uchycena, jak je tomu ale v připadě obecni úrovni? Je potřeba vztah veřejné správy a nestátnich neziskových organizaci na obecni úrovni formalizovat? Jsou motivy podpory nestátnich neziskových organizaci z obecni úrovně jiné než v prípadě vyšších úrovni veřejné 
správy? Jakých forem nabývá podpora nestátnich neziskových organizací na obecní úrovni? Na tyto otázky je v príspěvku zodpovězeno prostrednictvím reprezentativniho dotazníkového šetření, který probíhalo $v$ roce 2012 mezi respondenty zobecnich úr̆adì $v \check{C} R$ a také na základě analýzy sekundárnich zdrojů dát. Výsledky výzkumu ukazuji vysokou míru spolupráce obci a nestátnich neziskových organizaci, vysokou miru nepřmíe podpory nestátnich neziskových organizaci z obecni úrovné, a zároveň nízkou míru formalizace a nutnosti právniho ukotveni tohoto vztahu. Implementace podpory nestátnich neziskových organizaci na obecni úrovni se tak děje neformálně.

\section{Klíčová slova}

obce, nestátni neziskové organizace, veřejná politika, financování, nepř́má podpora

JEL classification: L38

\section{Introduction}

Public policy towards non-governmental organizations (NGOs) has been defined at the state level and titled the Czech Government Policy of Subsidies to NGOs (hereinafter referred to as GPS). It is a centrally coordinated government policy to support selected legal forms of NGO entities (foundations, endowment funds, public benefit corporations, church organisation and civic associations) in predefined areas called "main areas" (RVNNO, 2012a) under predetermined conditions called "Principles for Providing Subsidies from the State Budget to NGOs by Central Bodies of State Administration" (RVNNO, 2010). The essence of GPS as a government expenditure program lies in prioritizing selected legal forms of the beneficiaries. But this is not the full extent of public policy towards NGOs. At the same time, work has been conducted at this level to create a suitable environment for the existence and operations of NGOs in the Czech Republic (RVNNO, 2012b).

The support provided to NGOs at the state level takes the following forms: 1. subsidies (including services procured from NGOs as part of the support) (Prouzová \& Almani Tůmová, 2013), 2. favourable tax conditions for NGOs,(Pelc, 2010) 3. cooperation between authorities / ministries and the working groups and representatives of NGOs in predicting, planning, and implementing the goals and interests of the authorities and NGOs (Prouzová, 2012), 4. exceptional additional exemptions from administrative fees, and 5. opportunities to make use of communication and promotional channels of the authorities and ministries (Prouzová, 2012).

The major role in defining and developing the GPS is played by the Government Council for NGOs, which is a standing advising, initiating, and coordinating body of the government and also the basic institutionalized form of cooperation between NGOs and the government. According to the statutes of the Government Council for NGOs, the number of members of the body may not exceed 32, including the President of the Association of Regions of the Czech Republic and the President of the Union of Towns and Municipalities of the Czech Republic (RVNNO, 2012b). Although this public policy does not apply to lower levels of public administration, the Government Council for NGOs has been making efforts to extend it to the regional level, either through the existence of the Committee of the Regions of the Government Council for NGOs, the incorporation of Presidents of the Association of Regions of the Czech Republic and the Union of Towns and Municipalities of the Czech Republic to the Council of Government for NGOs, or the monitoring and presentation of data on financial flows to NGOs from all levels of public budgets.

With regional budgets, preference is given to direct funding of NGOs in the form of subsidies. Regional authorities also place great emphasis on cooperation with NGOs. More than half of the regional authorities have a department or employees specializing in NGO issues in the region. In five other regions, the NGO agenda is administered by several departments, depending on the areas in which the NGOs operate, and not only as providers of public services, in the region. Among the indirect forms of NGO financing, the most widely used are the communication and promotional channels of regional authorities (Prouzová, 2012). 
Some questions remain: 1. What are the forms of support and cooperation in the relationship between public administration and NGOs at the municipal level?; 2. What are the reasons for the cooperation and support?; and 3. Does this relationship need to be formalized as it is at higher levels of public administration?

\section{Objectives and Methods of the Research}

To determine the forms of and motives for support to NGOs at the municipal level and their cooperation, a representative questionnaire survey was carried out under the title "Municipalities of the Czech Republic and NGOs" (Prouzová, online). The aim of the representative quantitative questionnaire survey was to obtain findings about: 1. the attitude of a municipality towards NGOs and the reasons for the support provided to NGOs at the municipal level; 2 . subsidies provided to NGOs from municipal budgets and other forms of support to NGOs at the municipal level; and 3. the need to formalize this relationship.

This research project was implemented under the leadership of the author of this paper as a part of the Economics and Management of Nonprofit Organizations BKV_ERNO study programme at the Faculty of Economics and Administration of Masaryk University. Data were collected by students of this study programme in the spring of 2012. Data were acquired for the decisive year of 2010. The research was conducted with 71 representatives of municipal authorities from among the 6,251 municipalities in the country.

The representativeness of the quantitative survey was secured as follows. A complete set of municipalities was arranged in alphabetical order and individual municipalities were assigned numbers from 1 to 6,251. A random number generator selected 90 municipalities into the sample set. The rate of return was $78 \%$, which meets the condition of at least $60 \%$ return according to Punch (2008). Respondents were mayors or other individuals responsible for the NGO agenda at the municipal office. To verify the credibility of the collected data, control questions were placed in the questionnaire, and the answers were compared with secondary data sources, as shown in the following table.

Tab. 1: The structure, methods and data sources of the research

\begin{tabular}{|c|c|c|c|}
\hline \multicolumn{2}{|c|}{ Part of the research } & Research methods & Data sources \\
\hline 1 & $\begin{array}{l}\text { Sample characteristics of } \\
\text { the municipality - an } \\
\text { introduction to the } \\
\text { municipality }\end{array}$ & $\begin{array}{l}\text { Content analysis } \\
\text { secondary data }\end{array}$ & $\begin{array}{l}\text { - The municipality website } \\
\text { - Annual reports of the municipality } \\
\text { - Journal, newsletter, or other daily } \\
\text { papers published by the municipal } \\
\text { office } \\
\text { - http://portal.gov.cz } \\
\text { - Automated register of economic } \\
\text { entities } \\
\text { - http://www.czso.cz }\end{array}$ \\
\hline 2 & $\begin{array}{l}\text { Characteristics of the } \\
\text { relation between the } \\
\text { municipality and an NGO }\end{array}$ & $\begin{array}{l}\text { The questionnaire survey } \\
\text { using mail communication, } \\
\text { telephone or personal } \\
\text { interview. }\end{array}$ & $\begin{array}{l}\text { - Respondent participating in the } \\
\text { research }\end{array}$ \\
\hline 3 & Budget expenditures & $\begin{array}{l}\text { Collection of secondary } \\
\text { data sources }\end{array}$ & $\begin{array}{l}\text { - Central fiscal information system } \\
\text { - Report for the evaluation of budget } \\
\text { implementation }\end{array}$ \\
\hline 4 & Researcher's report & Observation & $\begin{array}{l}\text { - Student participating in the research } \\
\text { - Respondent participating in the } \\
\text { research }\end{array}$ \\
\hline
\end{tabular}




\section{Outcomes}

Research was conducted in 11 regions in the Czech Republic, in 16 villages with a population of less than 500 inhabitants, as well as 15 municipalities with a population of 500 to 999 inhabitants, 19 municipalities ranging from 1,000 to 1,999 inhabitants, 6 municipalities with a population from 2,000 to 2,999 inhabitants, and 15 municipalities with more than three thousand residents.

In $2010,85 \%$ of the municipalities collaborated with NGOs; $15 \%$ of the municipalities did not declare any form of cooperation with or support to NGOs, whether financial or in-kind. Within the $85 \%$ of collaborating municipalities, $10 \%$ of the municipalities usually cooperated with NGOs, especially in implementing joint projects for the population, or even common fund raising, but in 2010 there was no financial or in-kind support provided to NGOs at the municipal level. The remaining $75 \%$ of the municipalities provided financial or in-kind support to NGOs at the municipal level in $2010.58 \%$ of the municipalities provided financial and in-kind support to one or more NGOs in 2010.

Tab. 2: Three major types of support depending on the size of the municipality

\begin{tabular}{|c|c|c|c|c|c|}
\hline & $\begin{array}{l}\text { up to } \\
499 \text { inhabitants }\end{array}$ & $\begin{array}{lll}500 & - & 999 \\
\text { inhabitants } & \\
\end{array}$ & $\begin{array}{lll}1,000 \quad- & 1,999 \\
\text { inhabitants } & \\
\end{array}$ & $\begin{array}{lll}2,000 \quad- & 2,999 \\
\text { inhabitants } & \\
\end{array}$ & $\begin{array}{l}\text { over } \\
\text { inhabitants }\end{array}$ \\
\hline 1. & $\begin{array}{l}88 \% \\
* \text { Use of messag } \\
\text { boards of } \\
\text { the municipality / } \\
\text { city free of charge }\end{array}$ & $\begin{array}{l}93 \% \\
* \text { Use of the publid } \\
\text { address system } \\
\text { of the municipality } \\
\text { city free of charge }\end{array}$ & $\begin{array}{l}89 \% \\
* \text { Use of message } \\
\text { boards of } \\
\text { the municipality / city } \\
\text { free of charge }\end{array}$ & $\begin{array}{l}100 \% \\
* \text { Use of message } \\
\text { boards of the } \\
\text { municipality / city free } \\
\text { of charge } \\
* \text { Subsidies from the } \\
\text { budget of the } \\
\text { municipality / city }\end{array}$ & $\begin{array}{l}80 \% \\
* \text { Subsidies from the } \\
\text { budget of the } \\
\text { municipality / city } \\
* \text { Municipal premises } \\
\text { rented for free or for a } \\
\text { symbolic price }\end{array}$ \\
\hline 2. & $\begin{array}{l}81 \% \\
* \text { Use of the websit } \\
\text { of the municipality } \\
\text { city free of charge }\end{array}$ & $\begin{array}{l}80 \% \\
* \text { Municipal premises } \\
\text { rented for free or for a } \\
\text { symbolic price } \\
* \text { Use of message } \\
\text { boards of the } \\
\text { municipality / city } \\
\text { free of charge } \\
* \text { Use of the website } \\
\text { of the municipality } \\
\text { city free of charge }\end{array}$ & $\begin{array}{l}79 \% \\
* \text { Subsidies from the } \\
\text { budget of the } \\
\text { municipality / city } \\
* \text { Municipal premises } \\
\text { rented for free or for a } \\
\text { symbolic price } \\
\text { * Use of the publid } \\
\text { address system of the } \\
\text { municipality / city free } \\
\text { of charge } \\
\text { * Use of a periodical of } \\
\text { the municipality / city } \\
\text { free of charge }\end{array}$ & $\begin{array}{l}83 \% \\
* \text { Municipal premises } \\
\text { rented for free or for a } \\
\text { symbolic price } \\
* \text { Use of the public } \\
\text { address system of the } \\
\text { municipality free of } \\
\text { charge } \\
\text { * Use of a periodical of } \\
\text { the municipality / city } \\
\text { free of charge } \\
\text { * Use of the website of } \\
\text { the municipality / city } \\
\text { free of charge }\end{array}$ & $\begin{array}{l}80 \% \\
* \text { Use of a periodical } \\
\text { of the municipality / } \\
\text { city free of charge } \\
* \text { Use of message } \\
\text { boards of the } \\
\text { municipality / city free } \\
\text { of charge }\end{array}$ \\
\hline 3. & $\begin{array}{l}69 \% \\
* \text { Municipal premise } \\
\text { rented for free or for } \\
\text { symbolic price }\end{array}$ & $\begin{array}{l}67 \% \\
* \text { Lending of } \\
\text { technical and other } \\
\text { equipment of the } \\
\text { municipality / city } \\
* \text { Working time of } \\
\text { employees of the } \\
\text { municipal office } \\
* \text { Use of a periodical } \\
\text { of the municipality } \\
\text { city free of charge }\end{array}$ & $\begin{array}{l}68 \% \\
* \text { Use of the website of } \\
\text { the municipality / city } \\
\text { free of charge }\end{array}$ & $\begin{array}{l}67 \% \\
* \text { Lending of technical } \\
\text { and other equipment of } \\
\text { the municipality / city }\end{array}$ & $\begin{array}{l}60 \% \\
* \text { Use of the website } \\
\text { of the municipality / } \\
\text { city free of charge } \\
\text { * Lending of technical } \\
\text { and other equipment } \\
\text { of the municipality / } \\
\text { city } \\
\text { * Financial donations } \\
\text { * In-kind donations } \\
\text { * Use of the public } \\
\text { address system free of } \\
\text { charge }\end{array}$ \\
\hline
\end{tabular}

Source: drawn up by the author

Most often, the municipalities provide or are willing to provide subsidies (87\%) to NGOs, and rent them a space for free or at a symbolic price $(87 \%)$. The second most common form of support is the use of communication and promotional channels in the form of municipal boards (78\%), community websites $(76 \%)$, local radio stations $(75 \%)$, or periodically published municipal journals $(69 \%)$. The third most frequently provided forms of support are the loan of municipal assets and resources in the form of technical and other equipment of the municipality $(61 \%)$ and working time of employees of 
the municipal office for the needs of the organization (54\%). The fourth forms of support are in-kind $(60 \%)$ and financial $(60 \%)$ donations. Of the municipalities surveyed, $40 \%$ indicated other options for providing indirect assistance to NGOs. Finally, $28 \%$ of the surveyed municipalities provide or are willing to provide the following types of support, irrespective of the legal form of the recipient, i.e. whether it is an NGO or not.

The importance of NGOs, as seen by municipalities, lies in their engagement in creating good conditions for the activities of citizens, for example in sports, culture, free-time activities for children and young people, and maintaining local folklore and traditions. In this way, NGOs often extend the range of services that a municipality may provide for its citizens. Another reason to support NGOs is that inhabitants of a municipality are members of these organizations. An equally important reason is the support provided to municipalities by NGOs, for example, when NGOs are involved in cleaning the village or provide assistance during activities organised by other entities. Another motive to support NGOs is their ability to represent the community in various competitions. Last but not least, another reason is that municipalities do not want to lose the benefits arising from the presence of NGOs in the community. Municipalities that reported these reasons have finances earmarked for NGOs in their budgets for periodically recurring projects as well as for purposes that have not been defined in advance. These municipalities are willing to provide support from their budgets to the projects and activities of NGOs and to their operation and functioning.

Of the surveyed municipalities, $85 \%$ stated that there is no need for the NGO agenda to be formally addressed at the level of a department or function. For the remaining $15 \%$ of the municipalities, which address this agenda through a department or a function, this is an activity that is complementary to other activities executed by that department or function. This applies to both large and small municipalities.

In $17 \%$ of the municipalities, a legal document was issued by the municipal authority to govern the municipality's conduct towards, cooperation with, advantages for, or support to NGOs, mostly in the form of a resolution, or any form of a legal document other than the municipal ordinance, resolution, regulation, or order.

\section{Conclusion}

The research results show a high degree of cooperation between municipalities and NGOs, and a high level of support to NGOs at the municipal level both indirectly and financially in the form of subsidies from municipal budgets. This support is provided on the basis of specific cooperation and consequently good practices. As regards the $15 \%$ of the municipalities where there is no cooperation with NGOs, the question is whether this is due to bad practices or some other reason. The level of formalization and the need for legal confirmation of cooperation between NGOs and the municipality or support to NGOs at the municipal level is relatively low. A trend was identified for municipal budgets to provide support regardless of the legal form of the beneficiary, as was a tendency towards greater willingness to accept new forms of support in the municipalities that already provide some support.

Support to NGOs at the municipal level is not an expression of support provided to certain legal forms in a municipality; it is support for specific projects and areas where NGOs (and not only NGOs) are active. Alternatively, it is support to specific benefits arising from the existence of a given organization in a municipality. Thus, a bottom-up approach is adopted at the municipal level as regards implementation of the public policy of the government of the Czech Republic towards NGOs, and is conducted on the basis of specific examples of cooperation and needs of citizens, i.e., it is the innovative function that is attributed to NGOs. 


\section{Literature}

[1] PELC, V. Daňové podminky pưsobení neziskových subjektů. Praha: C. H. Beck, 2010.

[2] PROUZOVÁ, Z. Financování neziskových organizací u úrovní veřejné správy. Brno: Masaryk University, 2012.

[3] PROUZOVÁ, Z. Obce $\check{C} R$ a NNO. CVNS [online]. Accessed on 20 April 2013 from http://cvns.econ.muni.cz/projekty/53.

[4] PROUZOVÁ, Z., ALMANI TƯMOVÁ, K. Rozbor financování NNO z veřejných rozpočtů v roce 2011 [on-line]. Vláda České republiky, 2013. [cit. 29. 4. 2013] Dostupné z: $<$ http://www.vlada.cz/assets/ppov/rnno/dokumenty/rozbor_2011.pdf $>$.

[5] PUNCH, K. F. Základy kvantitativního šetření. Praha: Portál, 2008.

[6] RVNNO (2010). Zásady vlády pro poskytováni dotaci ze státniho rozpočtu České republiky nestátním neziskovým organizacím ústředními orgány státní správy [online]. Vláda České $\begin{array}{lllllll}\text { republiky. } & \text { [cit. } & 29 . & 4 & 2013] & \text { Dostupné }\end{array}$ $<$ http://kormoran.vlada.cz/usneseni/usneseni_webtest.nsf/0/15CD4A0EBBCA444EC12576BA00 2CF429/\$FILE/92\%20p\%C5\%99\%C3\%ADloha\%20w100201a.0092.pdf>.

[7] RVNNO (2012a). Statut Rady vlády pro nestátni neziskové organizace [online]. Vláda České republiky, 2012. [cit. 29. 4. 2013] Dostupné z: $<\mathrm{http} / /$ www.vlada.cz/assets/ppov/rnno/statut_RVNNO_2012.pdf $>$.

[8] RVNNO (2012b). Hlavni oblasti státni dotační politiky vǐči nestátním neziskovým organizacím pro rok 2013 [online]. Vláda České republiky, 2012. [on-line]. [cit. 29. 4. 2013] Dostupné z: $<$ http://racek.vlada.cz/usneseni/usneseni_webtest.nsf/0/C46B53639DB0236EC1257A21004303E 5/\$FILE/410\%20p\%C5\%99\%C3\%ADloha\%20w120613a.0410.pdf>.

The paper was written under the MU Student Project Grant titled Non-Profit Organizations in the Context of Problem Solving in the Modern Welfare State (MUNI/A/0982/2011). 